\title{
O znaczeniu obrazów w twórczości C. S. Lewisa
}

Do najważniejszych pojęć związanych z Clive'em Staplesem Lewisem - tak w odniesieniu do jego praktyki twórczej, jak w kontekście analiz jego dzieł - należy imaginacja. Peter J. Schackel w swojej monografii ${ }^{1}$ podjął jednak próbę udowodnienia, że dopiero uwzględnienie innej, równie ważnej perspektywy, którą wyznacza szeroko pojęta sztuka (a więc nie tylko rysunek czy malarstwo, ale i muzyka, taniec i architektura), pozwoli w pełni odczytać i zrozumieć twórczość autora cyklu narnijskiego. Podobną intuicją kierował się już Marek Oziewicz, skupiając się wszakże na stronie graficznej wydań kolejnych tomów Opowieści z Narnii². I choć dzisiaj znaczenie ilustracji w procesie odbioru dzieła nie budzi wątpliwości, to jednak przyjrzenie się tym zagadnieniom na przykładzie działalności Lewisa wydaje się pożądane - zwłaszcza że owa refleksja stanowi jednocześnie relację z dorastania do roli czytelnika i świadomego autora.

Jack, jak lubił o sobie mówić Lewis, już od najmłodszych lat chłonął nowe lektury, wypełniające większość przestrzeni w domu rodzinnym. To okres obcowania z literaturą w sposób dość przypadkowy, były tam bowiem „książki do czytania i nie do czytania, książki nadające się dla dzieci i zupełnie dla nich nieodpowiednie"3. Zabrakło natomiast tego, co Lewis miał w przyszłości cenić najbardziej - baśniowości. Chłopiec oddawał się ponadto innemu hobby: „[...] rysowaliśmy [z bratem - I. K.], o ile pamiętam, nieustannie"4, przy czym ważna wydaje się autorefleksja Lewisa:

[...] nie narysowaliśmy bodaj jednej kreski w zgodzie z jakimkolwiek, choćby najbardziej prymitywnym, pojęciem piękna. W naszych rysunkach można się doszukać akcji, poczucia humoru, pomysłowości, brak jednak przynajmniej szczątkowego wyczucia formy. [...] ta całkowita nieobecność piękna dobrze charakteryzuje nasze dzieciństwo. Ani jeden obraz wiszący w domu ojca nie przyciągał naszej uwagi i prawdę mówiąc, żaden na to nie zasługiwał’

Sztuka Edycji 1/2020 ISSN 2084-7963 (print) ISSN 2391-7903 (online) s. $75-87$

To istotna konstatacja. Stanowi bowiem jedną z ważniejszych przesłanek decydujących o kierunku rozwoju braci. Intelektualna atmosfera domu, wspomniany 
brak baśniowości i piękna, trudna relacja z ojcem - rozpolitykowanym człowiekiem o wysoce zretoryzowanym umyśle i specyficznym sposobie bycia - wszystko to zaważyło na zainteresowaniach, inspiracjach i poglądach rodzeństwa na długi czas.

Niemniej energia twórcza stosunkowo szybko znalazła swoje ujście, łącząc tym samym pasje młodych Lewisów. Powołali oni do życia i przez lata w wielu różnorodnych formach rozwijali swój własny, fikcyjny świat. Z fascynacji Jacka średniowieczem i zwierzętami w ubraniach oraz z zainteresowania Warniego Indiami i transportem kolejowym zrodziło się Boxen ${ }^{6}$ - kraina w równym stopniu tworzona co eksplorowana przez chłopców ${ }^{7}$. Dość powiedzieć, że ów twór miał charakter nadspodziewanie dojrzały ${ }^{8}$ : brak w nim śladu magii i cudowności, tematyka dotyczy kwestii politycznych, historycznych czy taktycznych, a stylizacje gatunkowe obejmują m.in. dramat, obrazek literacki, szkic encyklopedyczno-tekstologiczny, nawet traktat naukowy. Ważniejsze dla tych rozważań jest natomiast to, że wszystko było bogato ilustrowane, przy czym rysunki stanowiły równorzędną i integralną część tej sylwicznej całości. U ich genezy stoi nie tylko z gruntu dziecięca potrzeba zabawy, nie tylko potrzeba ekspresji czy też rodzaj eskapizmu' ${ }^{9}$, ale i jeszcze nieuporządkowana, w dużej części intuicyjna świadomość teoretyczna przejawiająca się choćby próbami nadania wytworowi wyobraźni pozorów prawdopodobieństwa. Ilustracje zaś - wśród nich mapy, schematy techniczne statków - były jednym ze służących temu narzędzi. Także ich forma ma znaczenie. Rysunki wykonano ołówkiem lub piórem w sposób nieco surowy, ale często (np. w wypadku schematów) dość szczegółowo, zwykle nie były kolorowane. Można w tym upatrywać dwojakiej przyczyny: drobnej niesprawności związanej z defektem genetycznym (każdy z Lewisów miał ruchomy wyłącznie jeden staw kciuka), ale i przywiązania do estetyki malarstwa średniowiecznego.

Następne lata były dla Clive’a burzliwe pod względem formacyjnym. Znaczącym przełomem (choć i tu należałoby mówić raczej o procesie) była jego konwersja, która miała dokonać się w 1931 roku. Do tego czasu autor zaczął już jednak dostrzegać piękno, odczuwać specyficznie pojmowaną Radość, ale i inaczej postrzegać książkę jako taką. Miał w tym swój udział jego przyjaciel, Arthur Greeves, który nauczył go doświadczania książki w wymiarze fizykalnym.
Kolejną rzeczą, której nauczył mnie Arthur, było zamiłowanie do książek jako do przedmiotów. [...] nie tylko szanował książki, był w nich wręcz zakochany. [...] Układ strony, faktura i zapach papieru, specyficzny szelest, jaki wydają różne gatunki papieru przy przewracaniu stron wszystko to stało się dla mnie zmysłową przyjemnością ${ }^{10}$.

Była to z pewnością jedna ze znajomości, która uwrażliwiła Lewisa na wiele zwykle niedostrzeganych drobiazgów, czemu w swojej biografii wielokrotnie dawał wyraz. Tę wrażliwość natomiast potrafił przeformułować na język literatury. Należy w końcu zaznaczyć, że w innych punktach przełomowych nierzadko towarzyszył Lewisowi... obraz. Pierwsze dziecięce fascynacje przebranymi zwierzętami inspirowane były pracami Johna Tenniela i Beatrix Potter ${ }^{11}$, za przebudzenie na piękno i oczarowanie Północą w dużej mierze odpowiadają rysunki Arthura Rackhama ${ }^{12}$, nawet opowieści narnijskie początkowo były tylko serią niezwiązanych ze sobą obrazów fauna, lwa czy kobiety w saniach ${ }^{13}$. Wszystko to - w dużym 
Tolkien usłyszał, że prace Baynes „redukują tekst dzieła do funkcji komentarza do ilustracji” ${ }^{17}$.

$\mathrm{Na}$ tę współpracę pewien wpływ miały względy genologiczne. Zarówno Lewis, jak i Tolkien stworzyli baśnie, a to gatunek, który niezależnie od adresata ${ }^{18}$ „lubi” ilustracje; obaj też byli miłośnikami (prywatnie i zawodowo) tak bliskiej gatunkowi fantasy stylistyki średniowiecznej, do której prace Baynes wyraźnie nawiązywały. Zwłaszcza jej smoki miały zrobić wrażenie na autorze Opowieści z Narnii, niestroniącego w swojej twórczości od fantastycznych stworzeń. Na pewno ujęła go też oszczędność środków przez nią stosowanych pióro i ołówek stanowiły jej główne (podobnie jak Lewisa w dzieciństwie) narzędzia.

Współpraca obojga nie była intensywna. Lewis przekazał ilustratorce swoje pierwsze szkice, zwłaszcza mapy i schemat statku, aby mogła odwzorować wykreowany przez niego świat bez fabularnych zafałszowań. Nie nadzorował całego procesu twórczego i niekiedy odpowiadał tylko na wątpliwości formułowane przez Baynes:

\begin{tabular}{l|c}
$\begin{array}{l}\text { Dr Lewis i ja prawie nie korespon- } \\
\text { dowaliśmy w sprawie ilustracji } \\
\text { do jego książek. Był autorem } \\
\text { najbardziej uprzejmym i toleran- } \\
\text { cyjnym - wydawał się zadowolo- }\end{array}$ & Ilustracje Baynes \\
zyobrażeniowym kształcie & opisanych obrazów
\end{tabular}
ny z pozostawienia wszystkiego w moich zupełnie niedoświadczonych rękach! Raz czy dwa pytałam o wygląd postaci, jaki miał na myśli, na przykład w wypadku Błotosmętka, i wówczas udzielał mi wyjaśnień, ale poza tym niczego nie komentował ani nie krytykował, choć rysunki były dalekie od doskonałości, a najprawdopodobniej także od tego, co widział w swoim umyśle. [...] Z tego, co pamiętam, zaledwie raz poprosił mnie o zmianę - $\mathrm{i}$ to $\mathrm{z}$ wielkimi przeprosinami [...], kiedy już krytykował, robił to w sposób tak uprzejmy, że naprawdę nie wyglądało to na krytykę. [...] Miałam uczucie, że uważał, iż skoro wreszcie zakończył opowieść [...], reszta pracy należała do kogoś innego i nie powinien się w nią mieszać ${ }^{19}$.

Chociaż Lewis bardzo cenił prace Baynes ${ }^{20}$, to jednak w jego odbiorze ilustracji obecna była także krytyka. Narysowane dzieci, zwłaszcza na początku, uważał za brzydkie - po premierze pierwszej części bezpośrednio poprosił nawet, by Baynes postarała się rysować je ładniej. Nie bardzo podobały mu się też wizerunki lwa, a niekiedy nawet, chwaląc jej osiągnięcia, dodawał jakąś uwagę:
Z zachwytem obserwuję [...], że pani ilustracje do każdej kolejnej książki są coraz lepsze: tak miło jest być świadkiem rozwoju artysty! (Gdyby tylko mogła pani wziąć sześć miesięcy urlopu i poświęcić je anatomii, pani możliwości byłyby nieograniczone) $)^{21}$.

Rzadko korespondowali i niemal się nie widywali, a ich wzajemne nastawienie było nacechowane pewnym rodzajem skrępowania:

\begin{abstract}
Wydaje się jednak, że Lewis nie zdawał sobie sprawy, jak wielki jawił się komuś tak skromnemu i samodzielnemu jak panna Baynes, powiedział mi, że uważał ją za zbyt nieśmiałą, by rozmawiać z nią tak szczerze, jak powinien by ${ }^{22}$.
\end{abstract}

Nie potrafi rysować lwów, ale jest tak dobra, i piękna, i delikatna, że nie mogę jej tego powiedzieć ${ }^{23}$.

Wszystko to jednak nie wpłynęło negatywnie na rezultat prac obojga. Walter Hooper połączenie tekstu Lewisa z obrazami Baynes zaliczył do najbardziej trafnych i harmonijnych, z jakimi się spotkał. Nie był w tej opinii odosobniony, co wydaje się potwierdzać przyznanie Ostatniej bitwie nagrody dla najpiękniejszej książki dziecięcej 1956 roku (Carnegie Medal). Zgadzał się z tym w końcu i Lewis, w odpowiedzi na list z gratulacjami od Baynes podkreślając: „Czy to nie jest raczej nasza nagroda?" ${ }^{24}$. Najprawdopodobniej o tym efekcie zadecydowała więc podobna wrażliwość i pokrewieństwa na poziomie imaginacyjności obojga twórców. Ilustracje Baynes zaważyły na wyobrażeniowym kształcie opisanych obrazów, na kierunku lektury i sposobie konkretyzowania całego świata przedstawionego - nie tylko jako figury związane ze znaczeniem słów, ale i jako byty od tych słów wyemancypowane. Marek Oziewicz w odniesieniu do septalogii mówił nawet o „opowieści obrazów”, „opowieści równoległej”. Istotę tego zjawiska dość szybko zrewidowały następne wydania, a ściślej: zmiany w tych wydaniach wprowadzane.

Już pierwszy amerykański wydawca Opowieści z Narnii, Macmillan, zrezygnował z wielu (niekiedy nawet połowy) oryginalnych ilustracji, w późniejszych latach podjął też próbę zmiany ilustratora. Dużych ingerencji dokonał także Collier Books: główny wydawca serii między 1970 a 1994 rokiem pominął wszystkie mapy oraz zdecydowaną większość 
ilustracji, pozostawiając po jednej dla każdego rozdziału (w wypadku części pierwszej było to siedemnaście z czterdziestu ośmiu oryginalnych ilustracji; połowa była w dodatku niekompletna). To ogromna ingerencja, zwłaszcza w książce, która tak wiele zawdzięcza warstwie graficznej. Biorąc pod uwagę, że cały cykl uzupełnia aż dwieście osiemdziesiąt siedem ilustracji i pięć map, tak znaczne ich okrojenie stanowi wykroczenie wobec dzieła i czytelnika. Nic dziwnego, że właśnie w takich kategoriach postrzegają owe zabiegi badacze:

Kiedy później trafiłem na w pełni ilustrowane wydania, poczułem, że nie tyle mam do czynienia $z$ innym wydaniem, ile wręcz z zupełnie inną książką. Doświadczenia imaginacyjne zostały istotnie wzbogacone ${ }^{25}$.

[...] zabiegi takie są bezsprzecznie - niezależnie od intencji wydawcy oraz rezultatu - ingerencją w głębokie pokłady znaczeniowe utworu ${ }^{26}$.

Oziewicz nie bez racji formułuje swoją ocenę w odniesieniu do książek, których „oryginalne wydania były w integralny sposób splecione z ilustracjami”27. Trudno jednak zapomnieć, że w wypadku Lewisa ów związek zaczyna się znaczenie wcześniej niż na etapie publikacji, a jest efektem w równej mierze: wrażliwości czy swego rodzaju dziecięcości, plastyczności umysłu, własnej postawy czytelniczej, świadomości twórczej, a w końcu tak niekiedy przewrotnej (i z uwagi na obecność dwóch autorów bardziej skomplikowanej) kategorii woli autorskiej. Lewis miał bowiem wpływ na proces obrazowania i choć sprawował nad nim dość subtelną kontrolę, to przecież właśnie wizję Baynes uznał za zbieżną ze swoją własną ${ }^{28}$. Wiadomo też, że reagowałby w przypadku znaczących rozbieżności wobec własnego konceptu - czy to na poziomie artystycznym, czy też merytorycznym; tak było choćby w wypadku wspomnianego błędu ilustratorki, która postać płynącą w łodzi narysowała w niewłaściwym w stosunku do kierunku podróży usytuowaniu. Wydaje się to zatem dostatecznym argumentem za przyjęciem zaaprobowanej przez instancję autorską komplementarności dzieła wraz z wszelkimi wynikającymi z tego dla czytelnika i badacza konsekwencjami.

Warto chyba przyjrzeć się ilustracjom bliżej, z uwagi na obfitość materiału całkowicie arbitralnie ograniczając się do

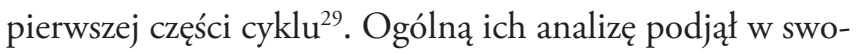
jej monografii Marek Oziewicz. Rozwijając jego ustalenia (zwłaszcza opierając się na kategorii „opowieści ilustracji”), można z powodzeniem mówić o swoistej poetyce prac
Baynes, koniecznie wszakże ujmowanych jako nierozdzielna całość. Badacz z uwagi na ich charakter wyróżnił ilustracje statyczne (duratywne i atrybutywne) oraz dynamiczne, a także - ze względu na występowanie - jednorazowe i powtarzalne. Za płynność tej obrazkowej opowieści, jej najprościej rozumianą fabularność, odpowiadałyby przede wszystkim ilustracje dynamiczne i powtarzalne. Dynamiczność w wykonaniu Baynes wybrzmiewa w sposób bezdyskusyjny, a jej prawdziwym popisem są sceny zbiorowe (ze szczególnym uwzględnieniem tłumów) - doskonale skomponowane, bogate w szczegóły, wymuszające na uważnym odbiorcy „wczytanie się" w obrazek, nierzadko nawet w detalach ściśle korespondujące z tekstem, pulsujące życiem. Ucztą dla oka są

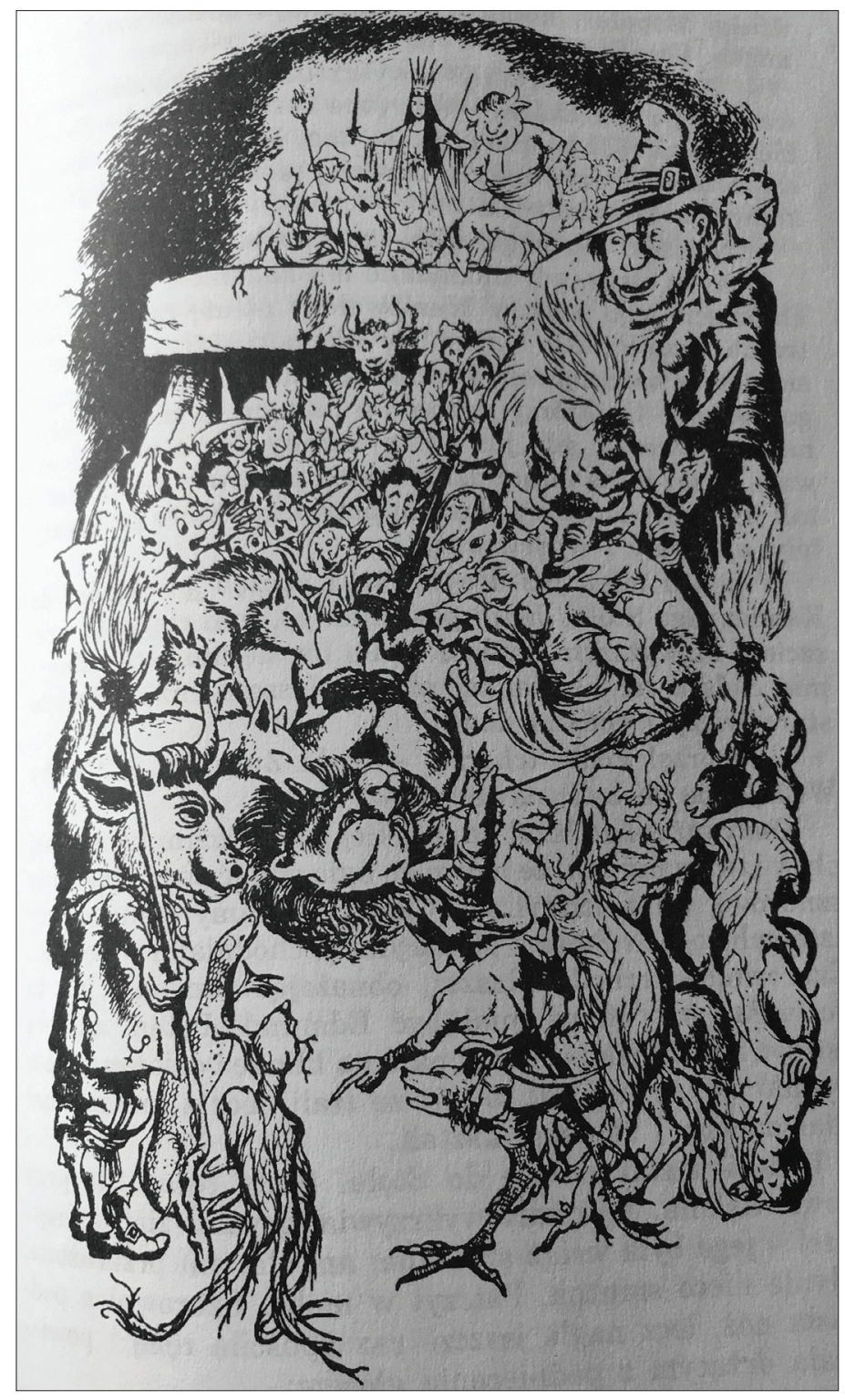

Il. 1. Aslan składany w ofierze na Kamiennym Stole, il. P. Baynes. Repr. za: C. S. Lewis, Lew, czarownica i stara szafa, tłum. A. Polkowski, Poznań 2002, s. 147 
choćby sceny bitewne czy moment ofiarowania Aslana na Kamiennym Stole (zob. il. 1), ale w skromniejszych realizacjach ilustratorka także nie zawodzi, czego przykładem może być scena pierwszego spotkania Edmunda i Białej Czarownicy (zob. il. 2). Patrzący niemal doświadcza wysiłku hamujących gwałtownie reniferów. Powtarzalność to z kolei zabieg tworzący mikroopowieść, serię skupioną wokół motywu czy postaci, zwykle odnoszącą się do szczególnie istotnych elementów historii. W wypadku Lwa, czarownicy i starej szafy autorka sięga po to rozwiązanie raz: przedstawiając samotną wędrówkę Edmunda do zamku Białej Czarownicy, będącej kulminacją jego zdrady, punktem decydującym o zmianie jego losu (co uwidacznia się najwyraźniej w zmianie nastawienia Czarownicy do chłopca), a zarazem wydarzeniem pociągającym za sobą ogromne konsekwencje dla innych bohaterów i wyznaczającym początek właściwej tułaczki chłopca (zob. il. 3-6).

Przeciwwagę (w dodatku wyraźnie zbilansowaną - stosunek rysunków w obu kategoriach to niemalże $1: 1$ ) stanowią ilustracje statyczne i jednorazowe, będące budulcem świata przedstawionego, elementem decydującym o ogólnej atmosferze utworu. Istotna w ich charakterystyce jest jedna

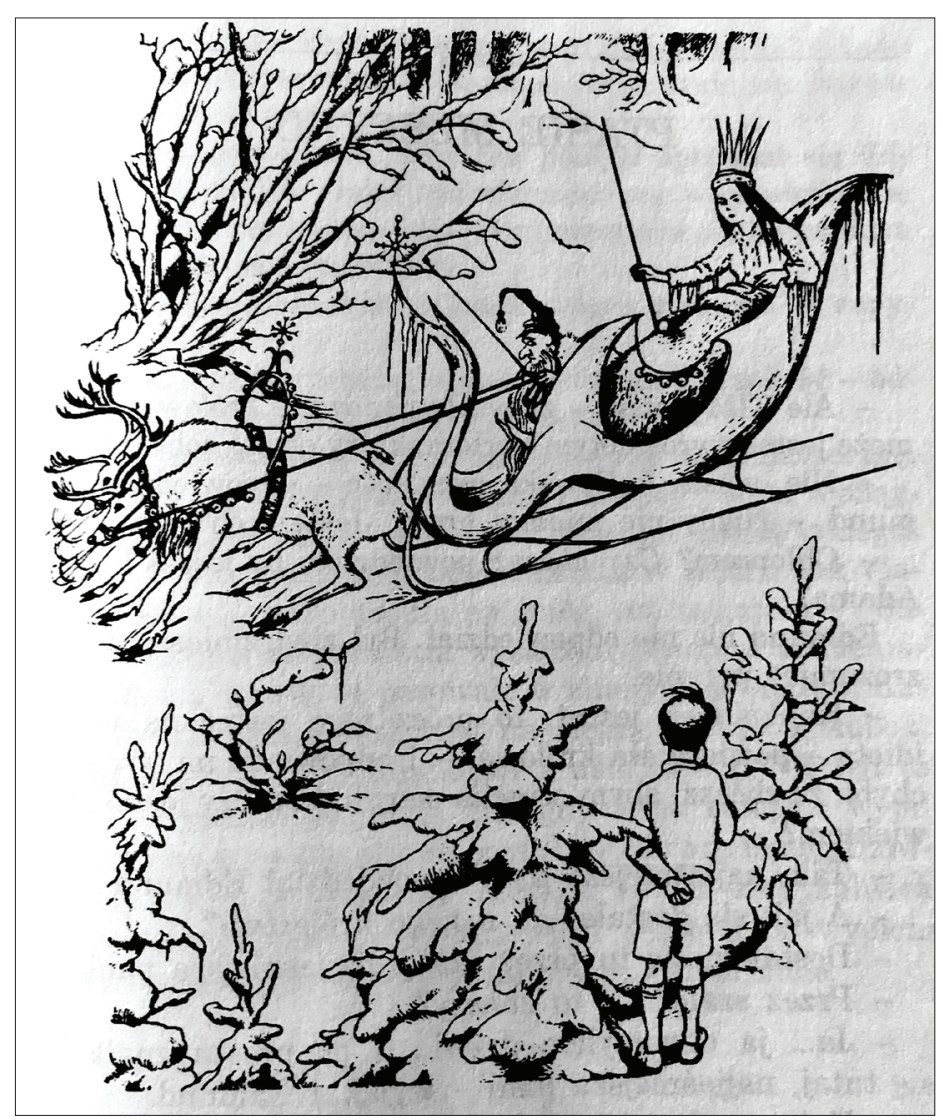

Il. 2. Edmund pierwszy raz spotyka Białą Czarownicę, il. P. Baynes. Repr. za: C. S. Lewis, Lew, czarownica i stara szafa, tłum. A. Polkowski, Poznań 2002, s. 36 z podstawowych funkcji ilustracji Opowieści spośród wskazanych przez Oziewicza - doprecyzowanie części narracyjnej przez wypełnienie wybranych miejsc niedookreślonych, w tym:

- relacji między postaciami,

- nastrojów i charakterów postaci,

- zdarzeń trudno wyobrażalnych (zwykle będących mieszanką elementów fantastycznych i rzeczywistych ${ }^{30}$.

Dzięki temu mamy więc pewność, że spotkania Łucji i Tumnusa oraz Edmunda i Białej Czarownicy miały zupełnie odmienny charakter i opierały się na innych odczuciach: w wypadku pierwszej pary bohaterów widać wzajemne zaufanie, a przede wszystkim gościnność fauna i oznaki roztaczanej nad dziewczynką opieki; druga para od początku ustawiona jest w relacji zależności, trudno też doszukać się pozytywnych emocji w czasie tego spotkania. Decydują o tym takie elementy, jak kompozycja, perspektywa, sposób przedstawienia postaci i związane z nimi atrybuty. Podobne obserwacje pozwalają też stwierdzić, że Czarownica z całą pewnością nie jest postacią pozytywną, a najwyraźniej podkreśla to kontrastowe (i dla wzmocnienia efektu skupione wyłącznie na postaciach, z pominięciem wszelkich elementów otoczenia) zestawienie Aslana i Czarownicy podczas ich negocjacji (zob. il. 8). Takie mechanizmy budowania znaczeń pojawiają się u Baynes dość często. Jedna z najciekawszych, wspaniale skomponowanych i przemyślanych ilustracji serii znalazła się w piątej części cyklu. Jest to zapowiadający przewrotność losów bohaterów rysunek, ukazujący pierwsze spotkanie Szasty i Bri (zob. il. 9) - ze względu na swoją pozycję społeczną i pełnione funkcje, obaj w postawach wyrażających podporządkowanie, „gubią się” poza centrum rysunku, by nieco później zaprezentować się jako główni bohaterowie, zmierzający zresztą do swego wyniesienia. Marek Oziewicz słusznie stwierdza, że tak trafna ekspozycja często jest formułą „mówiącą więcej niż literacki opis" 31.

Niemożliwość opisania przez autora każdego elementu jest oczywista i jednocześnie stanowi największą szansę dla wyobraźni ilustratora. Ten bowiem jest często pierwszym odbiorcą dzieła, choć jego aktywny dialog z autorem ma nieco inny wymiar niż w przypadku typowego czytelnika. To właśnie moment, w którym uwidacznia się decydująca rola ilustratora: filtra dla autorskiej wyobraźni, pośrednika między nim a czytelnikiem i równocześnie drugiego ogniwa współtworzącego wyobrażeniowy kształt świata przedstawionego oraz - w pewnym stopniu - narzucającego kierunek i sposób lektury. To ważne ustalenia - tym bardziej że analiza ilustracji Baynes (zwłaszcza tych statycznych i jednorazowych) pozwala 


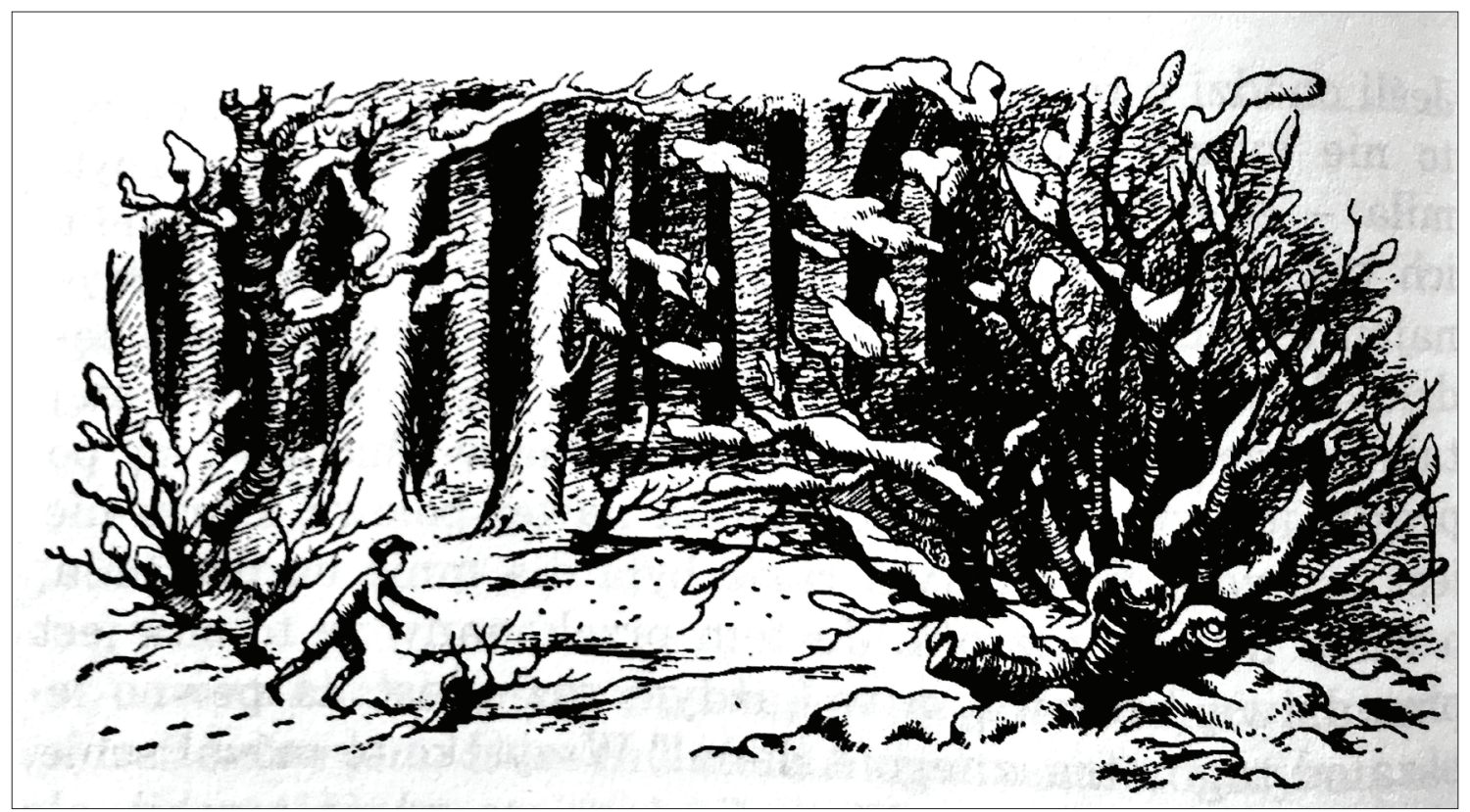

Il. 3. Tułaczka Edmunda, il. P. Baynes. Repr. za: C. S. Lewis, Lew, czarownica i stara szafa, tłum. A. Polkowski, Poznań 2002, s. 91

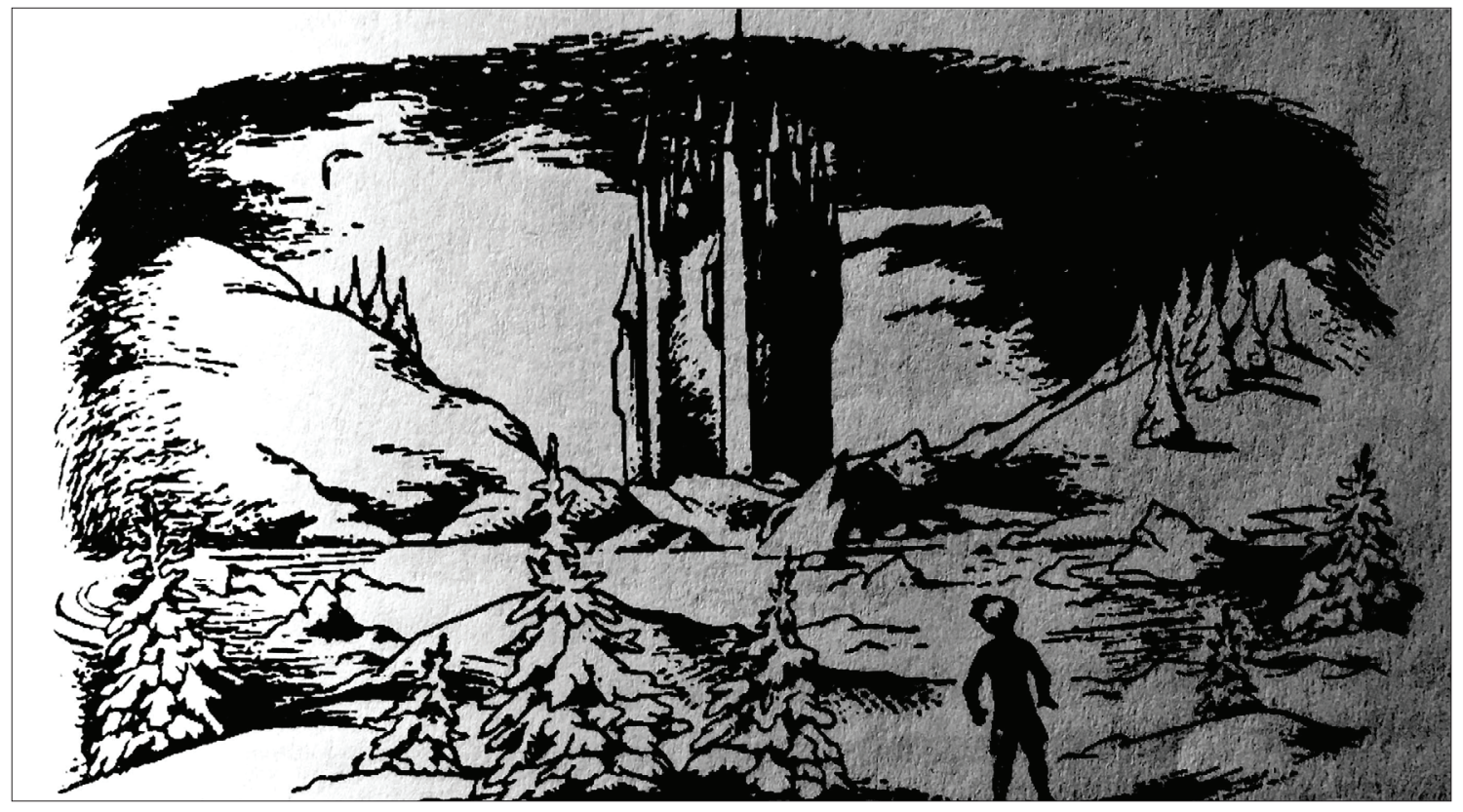

Il. 4. Tułaczka Edmunda, il. P. Baynes. Repr. za: C. S. Lewis, Lew, czarownica i stara szafa, tłum. A. Polkowski, Poznań 2002, s. 93

wysnuć wniosek, że najważniejszym bohaterem rysunków jest świat przedstawiony. W kontekście całego cyklu nie powinno to dziwić. Narnia Lewisa to kraina licząca ponad dwa tysiące lat, której powstanie i upadek autor przybliża w sposób szczególny. Zmieniają się więc bohaterowie, choć oczywiście część z nich powraca (a odzwierciedleniem tego rytmu jest ogólny profil ilustracji: z przewagą tych jednorazowych i mniejszą liczbą tych powtarzalnych ${ }^{32}$, wyznaczających jednak faktyczną Sztuka Edycji 1/2020 oś całej historii), czas fabularny, opisywane problemy - ale to, że przyglądając się uważniej już pierwszej części serii, można ową ideę rozpoznać na poziomie szaty graficznej, z całą pewnością świadczy o kunszcie ilustratorki, która potrafiła i tę intencję autora odzwierciedlić i uwypuklić.

Spośród czterdziestu ośmiu ilustracji połowę stanowią więc przedstawienia świata wyobrażonego - zupełnie pozbawione bohaterów lub ukazujące postaci w planach 
oddalonych, kiedy są one raczej pretekstem służącym zobrazowaniu otoczenia, często oddanego z pietyzmem. Takim pretekstem jest nawet wspomniana już wędrówka Edmunda, który będąc centrum tej „opowieści w opowieści”, nie jest przecież postacią centralną rysunków; na jego korzyść nie działa też przyjęta skala. Niejako na drugim biegunie znajdują się zaś stosowane niekiedy przez Baynes detale, nierzadko wykorzystane jako metonimia. W ten oszczędny sposób ilustratorka, po serii zimowych pejzaży - pełnowymiarowych, zdobnych, wieloelementowych - wprowadza motyw wiosenny (zob. il. 10), w zarysowanej sytuacji fabularnej znaczący przecież o wiele więcej, nie jest to tylko prosta zmiana pór roku. I właśnie wagę tych przemian zdają się podkreślać pojedyncze, niejako wypreparowane z całego otoczenia chelidonium i pierwiosnek, pokazane jeszcze z resztkami śniegu.

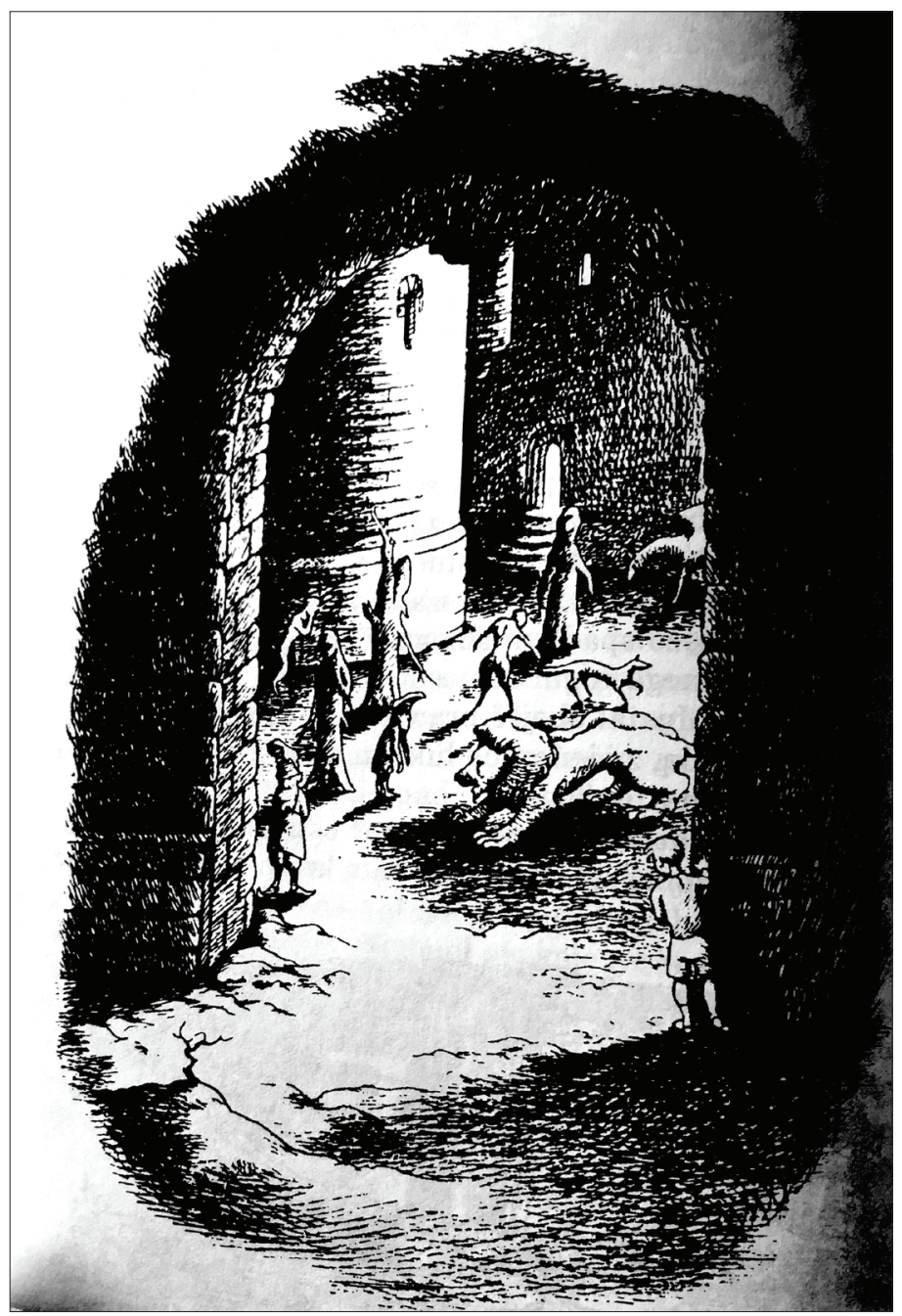

Il. 5. Tułaczka Edmunda, il. P. Baynes. Repr. za: C. S. Lewis, Lew, czarownica i stara szafa, tłum. A. Polkowski, Poznań 2002, s. 96
Nie mniej istotny jest sposób prowadzenia tej obrazkowej narracji. Na pierwszym rysunku widać niemal pusty pokój z ustawioną w rogu - a jednocześnie w centralnym punkcie kompozycji - szafą (zob. il. 11). Zapewne i tutaj działa zasada metonimiczna, szafa jest bowiem źródłem całej opowieści; to jej otwarcie (tak jak otwarcie książki) prowokuje następne wydarzenia. Przy tym pierwszym kontakcie zapoznajemy się więc z przestrzenią, nie z bohaterami, choć ich dyskretne cienie także są widoczne. Inne rysunki również prezentują przestrzeń - Latarniane Pustkowie, las, pieczarę fauna. I choć pojawia się już postać Łucji, widzianej od tyłu w czasie spaceru przez las czy skrytej za fotelem, to wciąż jest to etap wprowadzania w świat powieściowy. Nieco większą uwagę poświęca się już Edmundowi, stosunkowo późno natomiast pojawia się najstarsze rodzeństwo - dość powiedzieć, że całą czwórkę widzimy wyraźnie dopiero na dwudziestej pierwszej ilustracji, a zatem niemal w połowie narracji obrazkowej. Interesująco prowadzona jest także postać Aslana. Pierwszy raz „spotykamy” go w tym samym momencie, w którym spotykają go dzieci. Jest to chwila, w której przełamuje się narastające

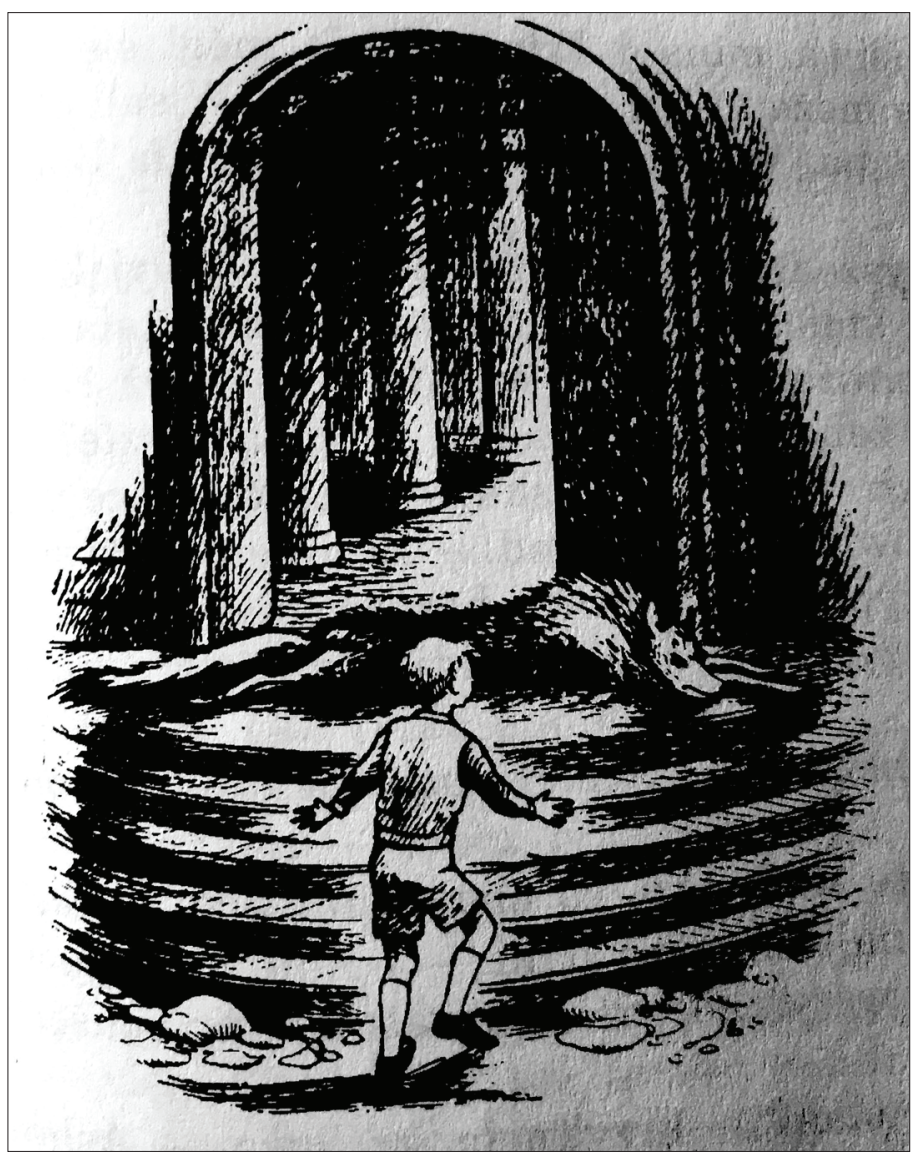

Il. 6. Tułaczka Edmunda, il. P. Baynes. Repr. za: C. S. Lewis, Lew, czarownica i stara szafa, thum. A. Polkowski, Poznań 2002, s. 98 


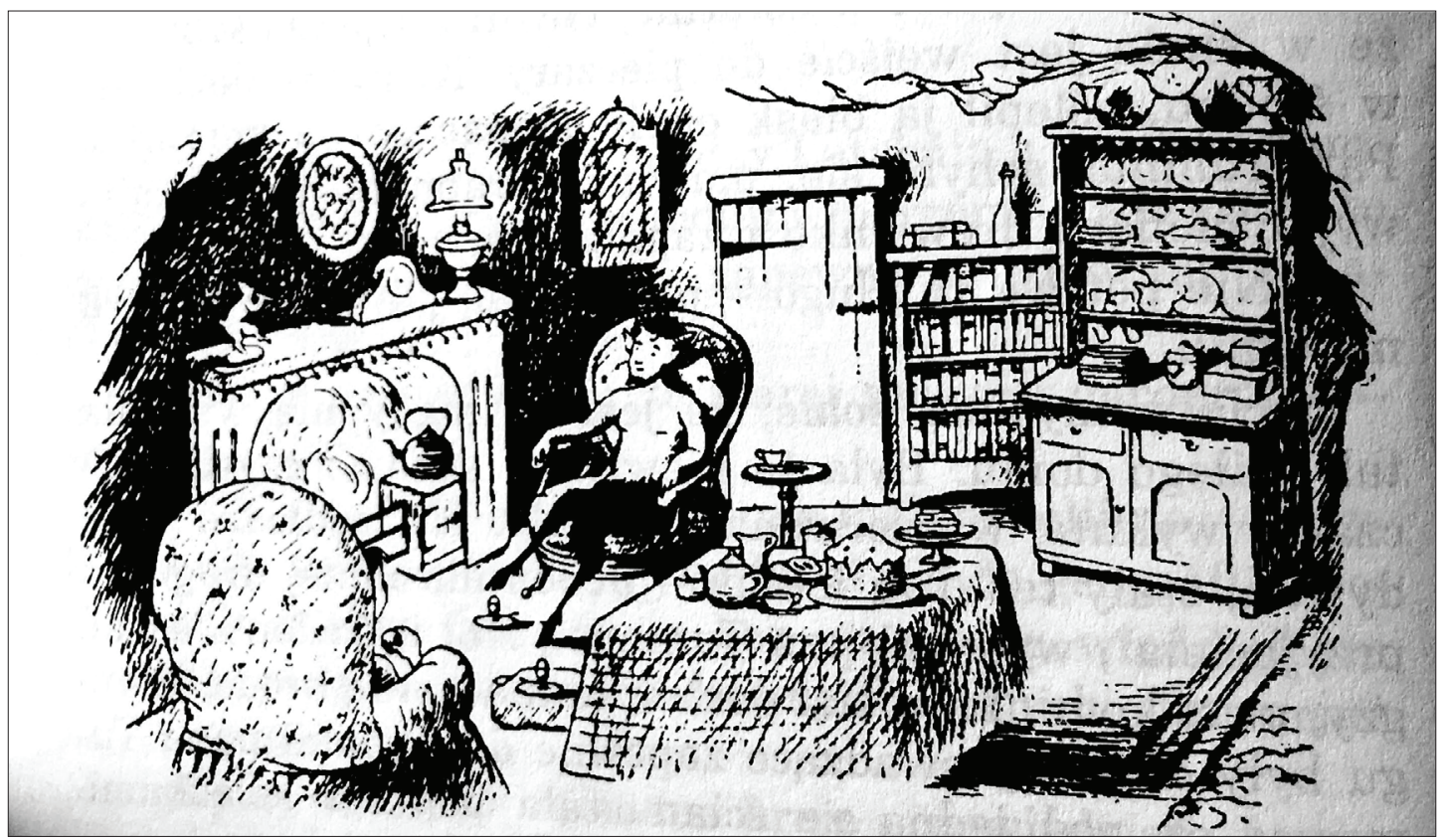

Il. 7. Łucja w pieczarze Tumnusa, il. P. Baynes. Repr. za: C. S. Lewis, Lew, czarownica i stara szafa, tłum. A. Polkowski, Poznań 2002 , s. 21

wokół niego napięcie, choć całkowicie nie znika ono już do końca. Lew jest tym, który spaja całą historię narnijską, będąc niejako jej uosobieniem. Ilustracje ukazują go jednak tylko sześciokrotnie, przy czym jego pojawienie się obserwujemy $\mathrm{w}$ wielkiej chwale $-\mathrm{z}$ orszakiem, ze sztandarami i w atmosferze święta. Ostatnie wystąpienie to już chwila triumfu nad Białą Czarownicą w czasie bitwy i w stosownym do sytuacji dynamicznym i tłumnym - ujęciu. Chociaż w trakcie lektury dowiadujemy się, że lew towarzyszył dzieciom jeszcze podczas koronacji, to w warstwie ilustracji ta ważna postać znika niemal niezauważalnie; funkcjonuje więc tak, jak w Lewisowskim opisie:

Gdzieś w środku tych zabaw i śpiewów Aslan niepostrzeżenie się oddalit. [...] Aslan przychodzi i odchodzi. Jednego dnia go widzisz, drugiego już nie. [...] Tak powinno byćs ${ }^{33}$.

Rysunki Baynes działają jednak także na innych poziomach, na co wskazują pozostałe podane przez Oziewicza funkcje. Poza najbardziej oczywistym, dekoracyjnym zastosowaniem mają one za zadanie wzmocnić efekt fantasy przez uprawdopodobnienie świata przedstawionego (tu: ogromna rola map) oraz zrealizować wiązaną z gatunkiem stylistykę. To zagadnienie odnosi się do zastosowanych przez ilustratorkę narzędzi i technik, które pozwalają z łatwością przywołać konwencję mediewistyczną.

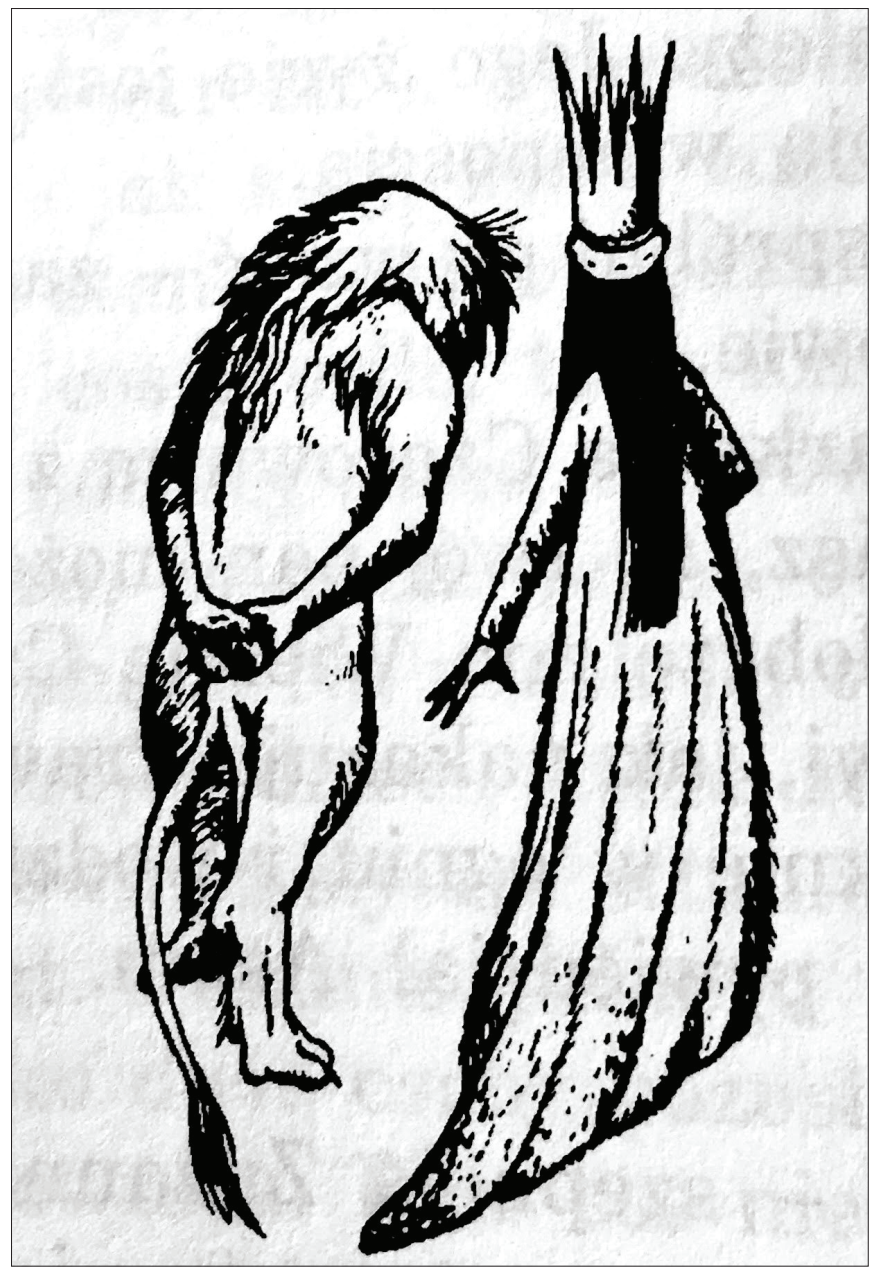

Il. 8. Negocjacje Aslana i Białej Czarownicy, il. P. Baynes. Repr. za: C. S. Lewis, Lew, czarownica i stara szafa, tłum. A. Polkowski, Poznań 2002, s. 139 


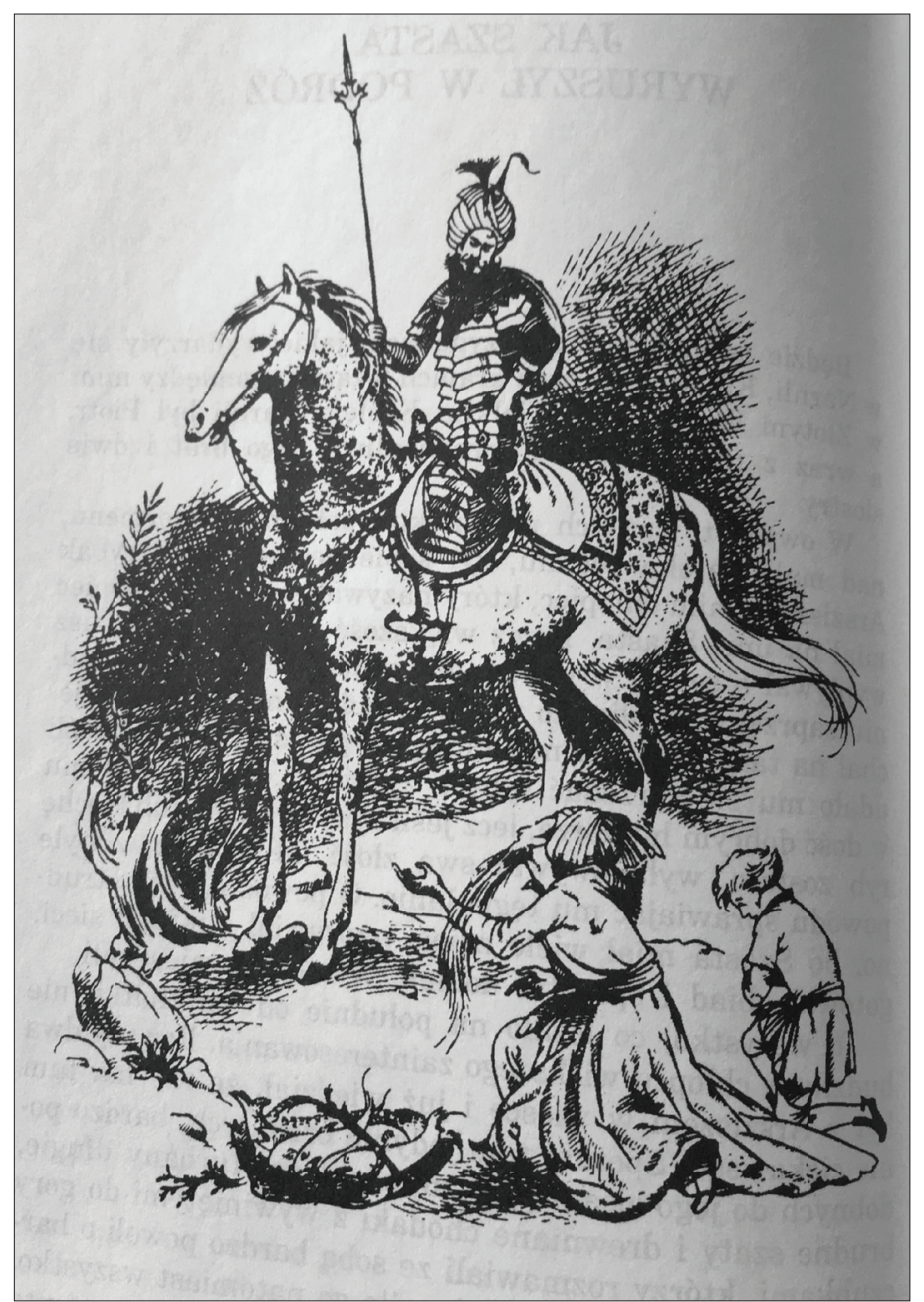

Il. 9. Spotkanie Szasty i konia Bri, il. P. Baynes. Repr. za: C. S. Lewis, Koń i jego chtopiec, tłum. A. Polkowski, Poznań 2002, s. 11

Choć taką analizę można pogłębiać (co zapewne powinien zrobić odbiorca powieści, ażeby wykorzystać cały jej potencjał), to wydaje się jasne, że prace Baynes - oczywiście jako zbiór - można postrzegać w kategoriach bliskich analizie dzieła tekstowego. Warto zaznaczyć, że oprócz wskazanych aspektów lokujących całość w sferze swoistej poetyki ilustratorka stosuje też inne tego rodzaju zabiegi: sięga po strukturalne powtórzenia (w ten sposób wyłaniają się odwrócone pary: widok ogólny pieczary Tumnusa, zob. il. 7 - zbliżenie zatroskanego fauna z jego fletem, zbliżenie pani Bobrowej przy maszynie - widok ogólny wnętrza domu Bobrów), klamry kompozycyjne (pierwsza ilustracja w książce to widok szafy i cieni przyglądających się jej dzieci, ostatnia przedstawia wypadające z tej samej szafy rodzeństwo), a nawet przedfabularne retrospekcje (realizowane w każdej z książek serii w postaci kilku wyraźniej zdobionych miniatur streszczających

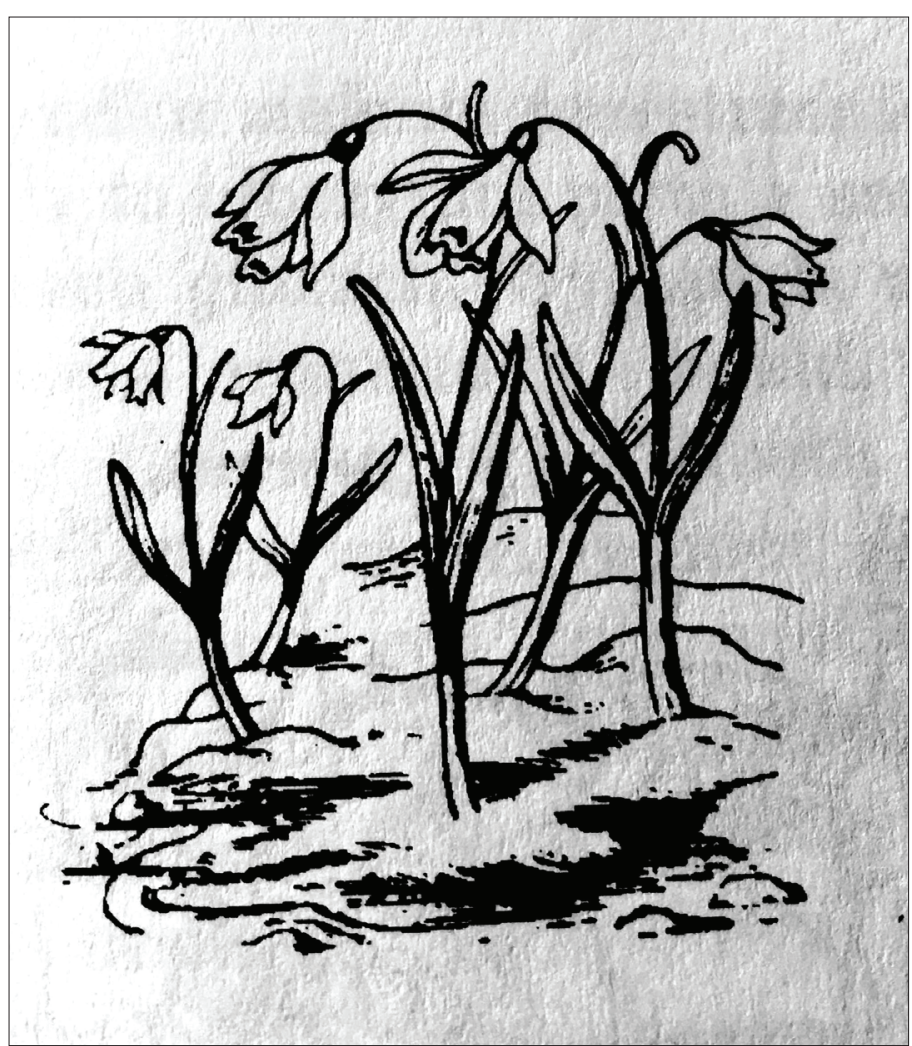

Il. 10. Detal, il. P. Baynes. Repr. za: C. S. Lewis, Lew, czarownica i stara szafa, thum. A. Polkowski, Poznań 2002, s. 119

wydarzenia). W ilustracjach można ponadto dopatrzyć się charakteru metonimicznego (np. odwracającego przyczynę i skutek), aluzyjnego, symbolicznego, a nawet deformacji perspektywy wynikających ze zmiany pozycji podmiotowej. Obraz staje się w końcu narzędziem prozodycznym. Wybory ilustratora dotyczące tego, co i w jaki sposób zostanie przedstawione, nakładają bowiem na te elementy dodatkowe akcenty. Są więc ilustracje „rozwijaną na krawędzi fabuły metatekstową opowieścią, która dopełniając tekst, istotnie przyczynia się do całkowitego efektu narnijskiej septologii”" ${ }^{34}$; stanowiąc tym samym rodzaj warstwy opowieści zasadniczej, dającej się jednak czytać w sposób niezależny.

Przedstawiona perspektywa niewątpliwie pozwala lokować działania amerykańskich wydawców w sferze zamachu na integralność semantyczną i artystyczną utworu ${ }^{35}$. „Ilustracje funkcjonują w owej koncepcji zgodnie z zamysłem, na podstawie którego powstały, a w ten sposób mówią swoim językiem"36 - pisze Oziewicz. Funkcjonują, czyli są percypowane, a przez to dopełniane. Lewis nie tylko przypisywał dziełu literackiemu funkcję performatywną ${ }^{37}$, ale i zdradzał intuicje tego, co dziś eksploruje antropologia czytelnictwa. 
Dostrzegał więc przede wszystkim czytelnika i wielką wagę przykładał do jakości, przebiegu i skutków lektury. To troska, której wielokrotnie dawał wyraz w swoich pismach (zarówno w ogłaszanych, jak i w korespondencji prywatnej) - także o charakterze teoretycznym czy warsztatowym, co sugeruje, że właściwym zwieńczeniem procesu tworzenia była dla niego właśnie aktualizacja dzieła literackiego w odbiorze czytelniczym. Wspaniale oddaje to jego stwierdzenie, że poezję tworzy tak naprawdę odbiorca, nie poeta ${ }^{38}$. Rozszerzenie tej myśli na ilustracje udowadnia, że także ich sens w pełni realizuje się na poziomie receptywnym.

Dzisiaj w analizach naukowych ilustracja zdaje się uzyskiwać poczesne miejsce. Rozpatruje się ją pod kątem artystycznym, edytorskim, a nawet psychologicznym czy translatologicznym; nierzadko, choć kojarzy się częściej z odbiorcą dziecięcym, dzieje się to z uwzględnieniem umowności (lub nawet irrelewantności) kategorii wieku, a nawet poza przekazywanym i ugruntowywanym na podstawie źródłosłowu przekonaniem o jej służebności wobec tekstu. Wpływ na ten stan rzeczy mają takie czynniki, jak rozwój instrumentarium naukowego z jednej strony czy ewolucja rynku wydawniczego z drugiej. Obraz - jak należałoby owo pojęcie rozszerzyć - stał się bowiem na tyle wyrazistym i atrakcyjnym środkiem wyrazu (a potencjalnie także samodzielnym nośnikiem znaczenia), że nie tylko może inspirować opowieść w tradycyjnym rozumieniu ${ }^{39}$, ale i zdominować publikację, redukując tekst do minimum bądź obywając się bez niego ${ }^{40}$. Decydującymi dla sposobu istnienia, a więc i postrzegania ilustracji, powinna być odgrywana przez nią rola oraz relacja wobec tekstu. Ograniczenie jej działania do funkcji ozdobnej i w sposób służebny uwypuklającej treści, bez uwzględnienia możliwości partnerskiego towarzyszenia przekazowi słownemu czy wyraźnej ich dominacji, jest w najlepszym razie niedocenieniem zagadnienia. $\mathrm{O}$ ile bowiem takie kategorie, jak nadrzędność/podrzędność czy następczość wobec tekstu, „okazują się przydatne wtedy, gdy ustalamy genezę ilustracji, [...] stają się bezużyteczne, gdy przechodzimy do mechanizmów odbioru" ${ }^{41}$. Te natomiast istotne są zwłaszcza w odniesieniu do młodego czytelnika.

Opowieści z Narnii można i trzeba rozpatrywać w kategoriach literatury dziecięcej, choć wymaga to kilku dopowiedzeń. Przede wszystkim należy unikać infantylizowania tego określenia, gdyż kryjący się za nim adresat definiowany jest na podstawie innych przesłanek niż wiek metrykalny. Lewis upatrywał w baśniach formy adresatywnie uniwersalnej.
Doskonale wiedział, że dziecko - główny ich odbiorca u początków tej formy był raczej odbiorcą przypadkowym, a jako autor starał się nawet „odzyskać” baśń dla czytelnika dorosłego. Prosta forma językowa cyklu nie unieważnia bogactwa kontekstów kulturowych, których odczytanie wymaga pewnej wiedzy o świecie, a troska o aspekt wizualny całości wynika z właściwego człowiekowi w ogóle poszukiwania piękna. Dziecięcość Lewisa (występująca niekiedy także jako chłopięcość) to jedna z kategorii stosowanych przez badaczy jego dzieł w odniesieniu do specyficznej wrażliwości, którą ten zwykle zupełnie świadomie się posługiwał i którą promował ${ }^{42}$. Jest to zresztą ta sama dziecięcość, która w pełni rozwinęła się u niego dopiero w kwiecie wieku. Jako dziecko był przecież chłopcem nad wyraz dojrzałym, wyjątkowo oczytanym i prezentującym bawiącą jego otoczenie, a tak nieprzystającą do wieku powagę. Tak ważne dla dziecięcości życie wyobraźni (a z nim pragnienie cudowności) w ocenie dorosłego już Lewisa było jednak pozostawiane bez należytej troski. Przekonał się o tym, gdy w 1935 roku gościł

małego chłopca wraz z jego matką, która - jak się wkrótce okazało - pozbawiła syna strawy duchowej, gdyż nigdy nie czytała ani nie opowiadała mu bajek. Uświadomienie sobie tego było dla Lewisa wstrząsem, ten zaś przerodził się w bodziec do przeciwdziałania temu za pomocą twórczości. Tak więc cykl niewątpliwie ma dziecięcego adresata, przy czym jest nim zarówno pozbawiony cudowności młody człowiek o „wygłodniałej imaginacji”, jak i wewnętrzne dziecko Lewisa, które na pewnym etapie swojego życia doświadczyło podobnych niedostatków. Jest nim w końcu każdy - bez względu na wiek - kto jest lub był w podobnej sytuacji.

Jak to wszystko odnosi się do zagadnienia ilustracji? Obrazowość wspiera realizację wpisanych w twórczość Lewisa celów. Obcowanie z dziełem literackim wzbogaca wyobraźnię, zwłaszcza jeśli działa wielokanałowo. Ilustracja wzmacnia więc ten efekt, a także - przez zdolność do uzupełniania głównej linii opowieści o dodatkowe szczegóły i wątki - uprawnia i zachęca do takich działań odbiorcę. Będąc już rodzajem interpretacji, staje się jednocześnie kluczem interpretacyjnym, który otwiera na nowe możliwości. Skuteczność i atrakcyjność tego oddziaływania manifestuje się oczywiście odmiennie dla osób w różnym wieku, ale niezależnie od tych różnic da się dostrzec we wszystkich grupach. Świadczy o tym m.in. przywołana już reakcja Schackela na odkrycie w pełni ilustrowanej wersji książki znanej mu z dzieciństwa ${ }^{43}$. Szczególne znaczenie 
owe mechanizmy mają jednak w przypadku dzieci - zwłaszcza dzieci jeszcze nieczytających. Ich pierwsze kontakty z książką opierają się bowiem na oglądaniu obrazków, właściwie "czytaniu” ich (niekiedy nawet towarzyszy temu tworzenie w odniesieniu do przedstawienia swojej własnej historii) albo na wysłuchaniu czytającego dorosłego. Ten ostatni przypadek analizuje jedna ze studentek Schackela, która z Narnią spotkała się po raz pierwszy dzięki rodzicom. Zaznacza, że chociaż (lub właśnie z tego powodu) nie była tą, która kontrolowała czytanie w jego najbardziej czynnościowym wymiarze (przewracanie stron, przyspieszanie lektury dla poznania rozwiązania), Narnia jej wyobrażenia stała się światem trwałym, zbudowanym na pewniejszych podstawach niż rzeczywistość. Uwolnienie lektury od koniecznych i odwracających uwagę gestów pozwoliło jej swobodnie podążać za powstającymi w procesie konkretyzacji obrazami. Ten wariant uczestniczenia w czytaniu również wspiera strona graficzna publikacji, dopełniając i ukierunkowując wyobraźnię. Owa wielokanałowość w znacznym stopniu wpisuje się w charakter prozy Lewisa, często określanej mianem sensualnej, i pomaga go rozwijać. Wspaniałymi przykładami tej sensualności są choćby fragmenty odnoszące się do posiłków czy opis przechodzenia przez szafę, w którym odtwarzana jest gradacja wrażeń zmysłowych towarzyszących temu doświadczeniu, uwzględniająca także chwilowe zawieszenie dominującego zwykle zmysłu wzroku. Niemniej na poziomie plastyczności opisu istotną rolę odgrywają właśnie ilustracje. Do ich korelacji z poetyką tekstu nawiązuje Marek Oziewicz, odnotowując, że autorowi:

[...] bardzo bliskie jest przemawianie przez formę i kolor, charakterystyczne dla malarstwa. Na poziomie ilustracji zamiłowanie to realizuje on przez wprowadzenie w przedmiotowy i obiektywny z założenia opis elementów spojrzenia subiektywnego, ujawniającego pozycję podmiotu utworu, który nie potrafi zrezygnować z radości „malarskiego" tworzenia. W ten sposób Lewis dokonuje transpozycji mowy wiązanej na przekaz plastyczny, powołując do życia drugą, symultaniczną z tekstem, „graficzną” linię opowieści ${ }^{44}$.

O ile więc przyjąć za Bogumiłą Kaniewską, że „ilustracja jest w pewien sposób, wtórny lub pierwotny, zaszczepiona w dziele literackim" ${ }^{\prime 4}$, to mamy w tym wypadku do czynienia z wzorcową, niemal transgresyjną realizacją tego założenia.

Ilustracja zwiększa w końcu oddziaływanie performatywne książki. Tolkien w swoim znakomitym eseju $O$ baśniach pisał, że w gatunek ten wpisane są możliwości uzdrawiania.

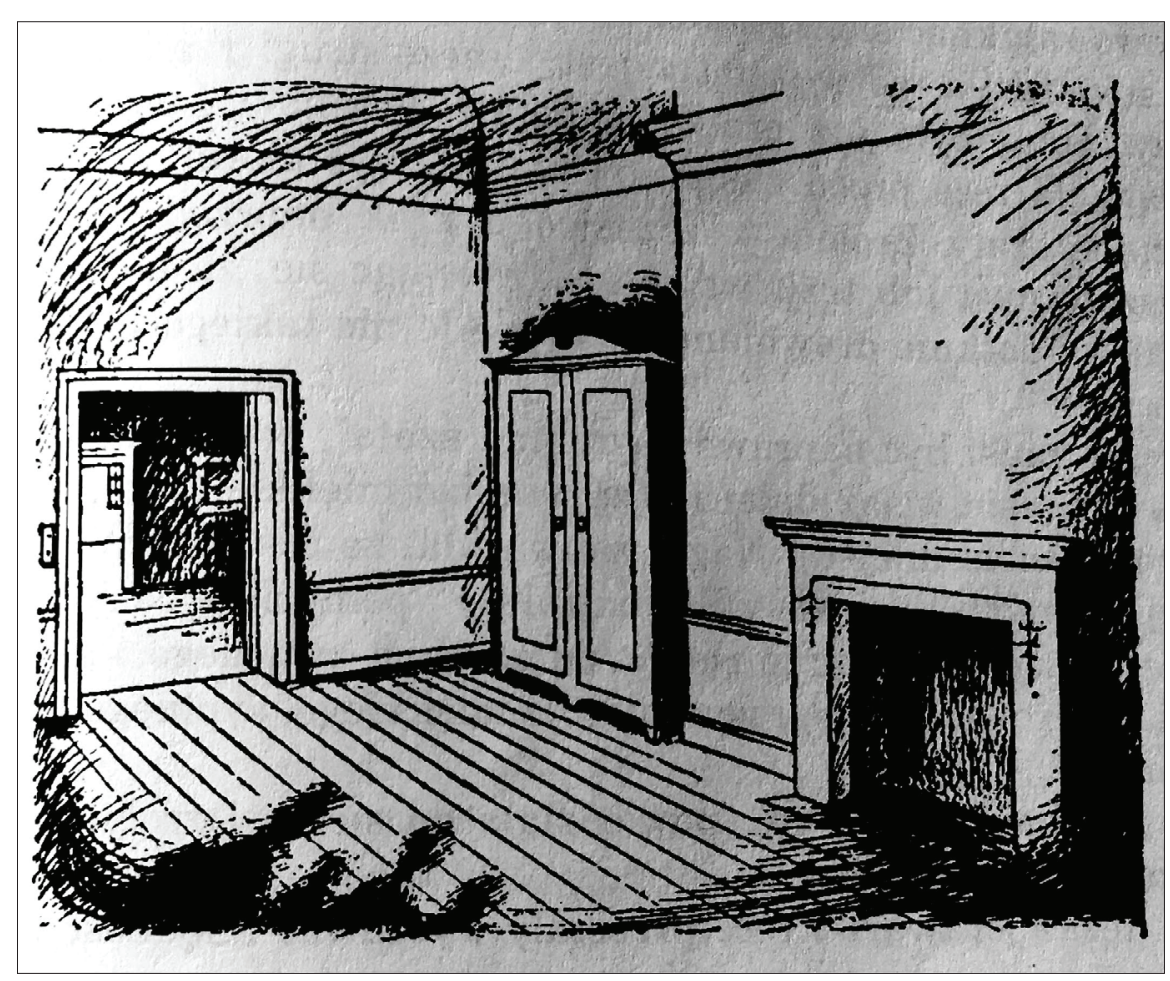

Il. 11. Szafa w domu Profesora - zaproszenie do opowieści, il. P. Baynes. Repr. za: C. S. Lewis, Lew, czarownica i stara szafa, tłum. A. Polkowski, Poznań 2002, s. 13 
Udowadniał, że zatopienie się w świecie rządzącym się prawidłami baśniowej magii nie tyle skutkuje oderwaniem od rzeczywistości, ile pozwala na nią spojrzeć inaczej - z dystansu, a przez to zdrowiej. Dziś, w świecie dobrze zaznajomionym z bajkoterapią, nie trzeba już do tego przekonywać, ale może warto zwrócić uwagę, że na całość tej ozdrowieńczej procedury wpływ mają także ilustracje. Te bowiem dla Ireny Słońskiej ${ }^{46}$, podobnie jak baśń dla Tolkiena, są jednym ze sposobów poznawania świata; tak przedstawionego, jak realnego - dodajmy. Wydaje się jednak, że uczestnicząc w tym procesie, pozwalają lepiej poznać także człowieka pojmowanego jako odrębny świat. Obcowanie z dziełem jest przecież formą obcowania z autorem, ale czytający może w trakcie lektury poznać inną, ważniejszą nawet osobę - samego siebie.

Biorąc pod uwagę różnorodność i skalę pełnionych przez ilustrację (rozumianą jako szczególny rodzaj paratekstu) funkcji, renesans refleksji naukowej z nią związanej nie powinien dziwić. Chociaż już wiele na tym polu uczyniono, wydaje się, że jej właściwy potencjał nadal czeka na odkrycie. Ogólna teoria ilustracji czy nawet studium przypadku nie zawsze są bowiem w stanie uwzględnić oddziaływanie długofalowe. Sylwetka Lewisa stanowi zatem wdzięczny materiał analityczny - nie tylko pozwala dostrzec funkcje konkretnych ilustracji w odniesieniu do konkretnego dzieła, ale też dosięgnąć procesów o charakterze formacyjnym, dotyczących rozwoju osobowości twórczej, wpływu na myślenie plastyczne czy zagadnień z zakresu korespondencji sztuk. Symbiotyczna zależność polegająca na wzmocnieniu obrazem plastyczności języka i fabularyzacji dzieła nieliterackiego wybrzmiewa tu wyraźnie. Co istotne: ogląd całości tych zjawisk i wzajemnych między nimi zależności i uwarunkowań pozwala na pogłębienie refleksji na ich temat, a potencjalnie także na wypracowanie wieloaspektowego modelu analitycznego.

Key Words: C. S. Lewis, illustrations, Pauline Baynes, The Chronicles of Narnia, text and image relations

Abstract: The article reflects on subject of illustration based on both: experience and writings of C. S. Lewis. A closer look at the author's developing relations to image (considering his childhood, adolescence and maturity) leads directly to history of co-operations with Pauline Baynes - creator of illustrations in first edition of The Chronicles of Narnia. The story which opens the cycle The Lion, the witch and the wardrobe was chosen to be the base of the article creation and is of most importance considering the analysis of text and image relations. The analyzing process, therefore, is derived from Marek Oziewicz's postulate of equality in treating story and image itself, understood as "story told by pictures". The structural analysis gives us the knowledge of fictional creations, gathered here as image poetics. This way of thinking provides a further perspective on illustration as an important factor of meaning and creativity.

P. J. Schackel, Imagination and Arts in C. S. Lewis Journeying to Namia and Other Worlds, Columbia 2011. Wszystkie cytaty, o ile nie zaznaczono inaczej, podaje w ttumaczeniu własnym.

2M. Oziewicz, Magiczny urok Namii. Poetyka i filozofia "Opowieści z Namii" C. S. Lewisa, Kraków 2005.

C. S. Lewis, Zaskoczony Radością, ttum. M. Sobolewska, Kraków 2010, s. 20.

${ }^{4}$ Ibidem, s. 15.

${ }^{5}$ Ibidem.

${ }^{6}$ C. S. i W. H. Lewis, Pakameria - Zanim powstała Namia: kroniki dziecięcej krainy marzeń, tłum. M. Juszkiewicz, Poznań 2009. Polska edycja opiera się na drugim wydaniu zbioru, jego tytuł został nieznacznie zmieniony (pierwotnie - Boxen: The Imaginary World of the Young C. S. Lewis, 1985) i zawiera kilka dodatkowych utworów - C. S. i W. H. Lewis, Boxen - Childhood Chronicles Before Namia, London 2008.

${ }^{7}$ I. Kropidło, Folklorystyczny budulec twórczości (od)dziecięcej - przypadek braci Lewisów, „Literatura Ludowa” 2017, nr 3.

${ }^{8}$ Szacuje się, że Jack pracował nad swoją krainą w okresie między ósmym a czternastym rokiem życia.

${ }^{9}$ Flora Lewis, matka Warniego i Jacka, zmarła bowiem, gdy chłopcy mieli odpowiednio trzynaście i dziesięć lat. Był to jednocześnie okres intensyfikacji prac nad Pakamerią.

${ }^{10} \mathrm{C}$. S. Lewis, Zaskoczony Radością, s. 238.

11 bidem, s. 26: "Mogłem też bez końca przeglądać zbiór prawie wszystkich numerów „Puncha« [...]. Stworzone przez Tenniela rysunkowe postacie Niedźwiedzia-Rosjanina, Lwa-Brytyjczyka, Krokodyla-Egipcjanina i innych narodowości zaspokajały moją namiętność do "przebranych zwierzątu, a jego nieudolne i pobieżne traktowanie roślinności utwierdzało mnie w moich niedociągnięciach. Wreszcie przyszła kolej na książki Beatrix Potter - pierwsze naprawdę piękne książki w moim życiu".

${ }^{12}$ Ibidem, s. 113: „llustracje te wydawały mi się [...] ucieleśnieniem muzyki Wagnera i stały się dla mnie przedmiotem nowej fascynacji".

${ }^{13}$ C. S. Lewis, It All Began with a Picture, w: idem, Of This and Other Worlds, London 1982 (cyt. za: M. Oziewicz, op. cit., s. 84).

${ }^{14}$ W Polsce wydana po raz pierwszy w 1962 roku jako Rudy Dżil i jego pies w ttumaczeniu Marii Skibniewskiej.

${ }^{15}$ Pauline Baynes (1922-2008), brytyjska ilustratorka, a także autorka nielicznych tekstów, wielokrotnie nagradzana. Ulubiona ilustratorka Tolkiena i Lewisa.

${ }^{16}$ P. J. Schackel, op. cit., s. 31. Nie bez powodu katalogi biblioteczne i księgarskie notują dla tej pozycji dwóch autorów: Tolkiena i Baynes.

${ }^{17} \mathrm{lbidem}$.

${ }^{18}$ Obaj autorzy stawiali sobie za cel odzyskanie baśni - zgodnie z genezą gatunku dla czytelnika dorosłego. Zob. np. J. R. R. Tolkien, O baśniach, w: idem, Drzewo i liść - Mythopoeia, ttum. J. Kokot, J. Z. Lichański i K. Sokołowski, Poznań 2000, s. 11-74.

${ }^{19}$ List Baynes do sekretarza Lewisa - Waltera Hoopera; W. Hooper, Past Watchful Dragons: The Origin, Interpretation, and Appreciation of the Chronicles of Namia, Eugene 2007, s. 77-78.

${ }^{20}$ Mawiał, że jest w nich zawsze „wykwintna subtelność", miał też czuć do nich "nieskończony podziw".

${ }^{21}$ W. Hooper, op. cit., s. $79-80$.

${ }^{22} \mathrm{lbidem}, \mathrm{s} .77$.

${ }^{23}$ D. Brown, Inside Namia: A Guide to Exploring The Lion, the Witch and the Wardrobe, Michigan 2005, s. 23.

${ }^{24}$ Ibidem, s. 24.

${ }^{25}$ P. J. Schackel, op. cit., s. 34

${ }^{26}$ M. Oziewicz, op. cit., s. 88.

${ }^{27}$ Ibidem.

${ }^{28}$ Warto dodać, że Baynes wróciła do swoich ilustracji, które na potrzeby wznowienia z okazii pięćdziesięciolecia Opowieści i setnych urodzin Lewisa pokolorowała. Już taka, niewielka zadawałoby się (a przede wszystkim - autorska!), zmiana wywołuje odmienne wrażenia estetyczne, ilustracje inaczej wspótistnieją z tekstem, dokonuje się przesunięcie stylistyczne. Jest to propozycja mająca zarówno zwolenników, jak i przeciwników.

${ }^{29}$ Pierwsza część, czyli (zgodnie z chronologią wydawania oraz układem przyjętym na rynku polskim) Lew, czarownica i stara szafa. Kolejność tomów nie jest kwestią bezdyskusyj- 
ną. Dla tej przykładowej analizy nie ma jednak większego znaczenia, można ją bowiem przeprowadzić na dowolnej części cyklu.

${ }^{30}$ M. Oziewicz, op. cit., s. 98.

${ }^{31}$ Ibidem, s. 99.

32 Przy czym powtarzalność nadal należy rozumieć w sensie skupienia wokół motywu, wydarzenia czy bohatera, w żadnym wydaniu nie powtarza się bowiem dwa razy dokładnie ta sama ilustracja (o ile nie stanowi ozdobnika rozdziału, karty tytułowej czy okładki - to jednak układy kompozycyjne naddane, niebędące częścią autorskiego układu).

${ }^{33}$ C. S. Lewis, Lew, czarownica i stara szafa, tłum. A. Polkowski, Poznań 2002, s. 176.

${ }^{34}$ M. Oziewicz, op. cit., s. 89.

${ }^{35}$ Polski czytelnik otrzymał kompletny przekaz. Choć początkowo staranność i jakość dostępnych na rynku publikacji nie prezentowała wysokiego poziomu, to już od pierwszego wydania owa integralność pozostała zachowana. Nie obyło się jednak bez pewnych błędów. Jeszcze w wydaniu z 1996 roku (w formie dwóch tomów) można zauważyć np. nieuzasadnione przesunięcie ilustracji, powodujące zaburzenie ciągu logicznego historii. Rysunek przedstawiający Aslana odczarowującego po swoim zmartwychwstaniu zamienionych w kamień narnijczyków (a więc jeszcze przed zakończeniem bitwy i uśmierceniem Czarownicy) znalazł się... w sąsiedztwie sceny koronacji rodzeństwa.

${ }^{36}$ M. Oziewicz, op. cit., s. 88.

${ }^{37}$ Podobnie jak Tolkien, wierzył, że dobra baśń może uzdrawiać, w micie zawiera się prawda, a powinnością literata jest karmienie wygłodniałej imaginacji czytelnika (zwłaszcza ale nie wyłącznie - dziecka) żyjącego w realiach dehumanizującej naukowości i dyskusyjnego etycznie postępu technologicznego.

${ }^{38}$ C. S. Lewis, The Personal Heresy: A Controversy, s. 16.

${ }^{39}$ Działo się to zresztą już znacznie wcześniej i na różne sposoby. Najczęściej chyba przywoływanym przykładem jest Klub Pickwicka Charlesa Dickensa - powieść odcinkowa z lat 1836-1837, której podstawę miały stanowić rysunki humorystyczne Roberta Seymoura (choć na etapie realizacji przyjęto nadrzędność tekstu). Są także utwory charakteryzujące się równoległością powstawania tekstu i ilustracji, co przekłada się na odmienny charakter relacji obu aspektów dzieła (np. wspomniana Pakameria braci Lewisów, Mały Książę Antoine'a Saint-Exupery'ego).

${ }^{40}$ Szczególna kategoria ostatniego przypadku bywają książki artystyczne - ich specyfika, ale i trudności wynikające z płynności definicyjnej pojęcia wymagają jednak pogłębionych refleksji, które nie mogą wybrzmieć w prezentowanym artykule.

B. Kaniewska, O ważności obrazków, czyli ilustracja w książce dziecięcej, w: Literatura w kręgu sztuki. Tematy - konteksty - medialne transformacje, pod red. S. Wysłouch i B. Przymuszały, Poznań 2016.

${ }^{42}$ Zob. np. H. Carpenter, Inklingowie: C. S. Lewis, J. R. R. Tolkien, Charles Williams i ich przyjaciele, tłum. Z. A. Królicki, Poznań 1999, s. 277-281.

${ }^{43}$ Por. s. 78.

${ }^{44}$ M. Oziewicz, op. cit., s. 103.

${ }^{45}$ B. Kaniewska, op. cit., s. 157.

${ }^{46}$ I. Słońska, Psychologiczne problemy ilustracji dla dzieci, Warszawa 1969, s. 11.

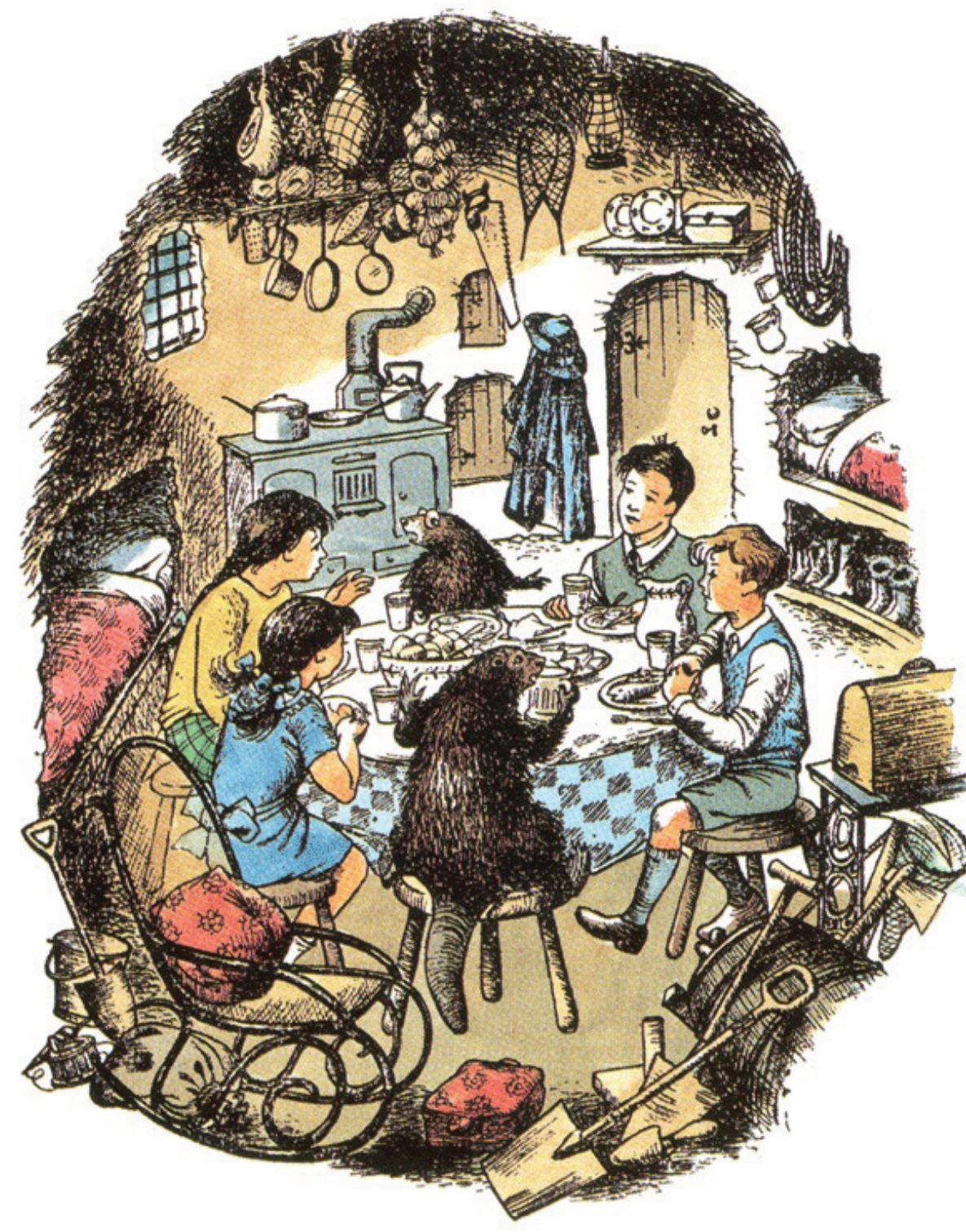

